\title{
Technological Change, Financial Innovation, and Diffusion in Banking
}

\author{
W. Scott Frame \\ Lawrence J. White \\ Prepared for The Oxford Handbook of Banking, $2^{\text {nd }}$ edn. \\ Allen N. Berger, Philip Molyneux, and John O.S. Wilson, eds.
}

\begin{abstract}
$\underline{\text { Abstract }}$
The commercial banking business has changed dramatically over the past 30 years, due in large part to technological change. The paper first describes the role of the financial system in economies and how technological change and financial innovation can affect social welfare. We then survey the literature relating to several specific financial innovations - broadly categorized as new products or services, new production processes, or new organizational forms - and evaluate them in the context of the broader economics literature on innovation. While much effort has been devoted to understanding the characteristics of users and adopters of financial innovations and the attendant welfare implications, we still know little about how and why financial innovations are initially developed.
\end{abstract}

Key words: technological change; financial innovation; diffusion; banking 


\section{Introduction}

The commercial banking business has changed dramatically over the past 30 years, due in large part to technological change. ${ }^{1}$ Advances in telecommunications, information technology, and financial theory and practice have jointly transformed many of the relationship-focused intermediaries of yesteryear into data-intensive risk management operations of today. Consistent with this, we now find many commercial banks embedded as part of global financial institutions that engage in a wide variety of financial activities.

To be more specific, technological changes relating to telecommunications and data processing have spurred financial innovations that have altered bank products and services and bank production processes. For example, the ability to use applied statistics cost-effectively (via software and computing power) has markedly altered the process of financial intermediation. Retail loan applications are now routinely evaluated using credit scoring tools, rather than using human judgment. Such an approach makes underwriting much more transparent to third parties and hence facilitates secondary markets for retail loans, such as credit card debt and mortgages, via securitization. Statistically based risk measurement tools are also used to measure and manage other types of credit risks - as well as market risks - on an ongoing basis across entire portfolios. $^{2}$ After the global financial crisis, these tools have been leveraged to comply with new regulatory stress testing requirements for systemically important financial institutions.

\footnotetext{
1 Restrictions on commercial banks' ability to diversify geographically and across product space were also significantly relaxed during this time, especially in the United States. This trend has significantly reinforced technological change in terms of driving the observed evolution of commercial banking over the past 30 years. See Berger, Kashyap, and Scalise (1995) for discussion of the role of technological and regulatory changes in transforming the U.S. banking industry.

${ }^{2}$ Related to this, there has been important innovation in the development of indexes - such as house price indexes, securities price indexes, and volatility indexes - that have aided in the measurement and management of risks,
} 
This chapter will describe how technological change has spurred financial innovations that have driven the aforementioned changes in commercial banking over the past 30 years. In this respect, our survey is similar to that of Berger (2003). However, our analysis distinguishes itself by reviewing the literature on a larger number of new banking technologies and synthesizing these studies in the context of the broader economics literature on innovation. In this way, the chapter is more like our own previous survey of empirical studies of financial innovation (Frame and White, 2004). We note that this survey is largely U.S.-centric, owing to our own experiences, the fact that many financial innovations originate in the U.S., and the fact that most studies of such innovations rely on U.S. data. Before proceeding, it will be helpful to understand better what is meant by financial innovation.

\section{Background: The Role of Finance and Financial Innovation}

As noted by Merton (1992, p. 12), the primary function of a financial system is to facilitate the allocation and deployment of economic resources, both spatially and across time, in an uncertain environment. This function encompasses a payments system with a medium of exchange; the transfer of resources from savers to borrowers; the gathering of savings for pure time transformation (i.e., consumption smoothing); and the reduction of risk through insurance and diversification.

The operation of a financial system involves real resource costs (labor, materials, and capital) employed by financial intermediaries (e.g., commercial banks) and by financial facilitators (e.g., mortgage brokers). Much of these resources are expended in the data collection and analyses

including the innovative development of financial instruments that are based on these indexes. The importance of 
in which financial market participants engage so as to deal with problems of asymmetric information. There are also uncertainties about future states of the world that generate risks, which for risk-averse individuals represent costs. In this environment, new financial products and services that can better satisfy financial system participants' demands should generally be welcomed by those participants.

Hence, we define a financial innovation as something new that reduces costs, reduces risks, or provides an improved product/service/instrument that better satisfies financial system participants’ demands. Financial innovations can be grouped as new products or services; new production processes; or new organizational forms. Of course, if a new intermediate product or service is created and used by banks, it may then become part of a new financial production process.

The centrality of finance in an economy and its importance for economic growth (e.g., Levine 1997) naturally raises the importance of financial innovation - and its diffusion. Since finance is a facilitator of virtually all production activity and much consumption activity, improvements in the financial sector will have direct positive ramifications throughout an economy. Further, since better finance can encourage more saving and investment and can also encourage better (more productive) investment decisions, these indirect positive effects from financial innovation add further to its value for an economy. This positive view of financial innovation has been discussed in a number of articles, most notably: Van Horne (1985), Miller (1986, 1992), Merton (1992, 1995), Tufano (2003), Frame and White (2004), and Allen (2012).

such indexes is a theme that underlies many of the essays in Haliassos (2013). 
The recent global financial crisis has led some observers to cast doubt on the usefulness of most financial innovation - seeing such activity as being largely associated with financial instability and financial malpractice. ${ }^{3}$ For example, Paul Volcker (2009) famously remarked “...the most important financial innovation that I have seen [in] the past 20 years is the automatic teller machine” after earlier highlighting two financial innovations - “...credit-default swaps and collateralized debt obligations - which took us right to the brink of disaster.” Similarly, Paul Krugman (2007) characterized "financial innovation" as "two words that should, from now on, strike fear into investors' hearts" since the recent innovations "were sold on false pretenses... [and instead] spread confusion, luring investors into taking on more risk than they realized.

While such a reevaluation is natural in light of the financial crisis, it is important to recognize that not every financial innovation will be welfare enhancing or successful. Innovation involves trial-and-error, and failures can be costly - especially for widely diffused innovations (e.g., Lerner and Tufano, 2011). So, when one suggests that financial innovation is beneficial, this should be viewed as "on net". ${ }^{4}$ Consistent with these conjectures, Beck, Chen, Lin, and Song (2012) conduct a cross-country analysis and find that financial innovation is associated with higher (but more volatile) economic growth and with greater bank fragility.

Given the importance of financial innovation, identifying the environmental conditions that are conducive to such changes is worthwhile. The general innovation literature in economics has sought to uncover the environmental conditions that affect the stream of innovations -

\footnotetext{
${ }^{3}$ Thakor (2012) and Gennaioli, Shleifer, and Vishny (2012) are recent examples of theoretical research that attempts to tie financial innovation and financial instability. Both provide models where banks innovate by making new loans or creating new securities; but then altered information or beliefs results in runs or panics. Henderson and Pearson (2011) provide recent empirical analysis of a welfare-reducing financial innovation.
} 
focusing on hypotheses concerning roughly five structural conditions: (1) the market power of enterprises; (2) the size of enterprises; (3) technological opportunity; (4) appropriability; and (5) product market demand conditions. See Cohen and Levin (1989) and Cohen (1995) for comprehensive surveys of this literature.

Campbell (1988) offers four such conditions specifically in the context of financial innovation. The first relates to underlying technologies and the ability of technological improvements to increase efficiency. Here we point to how the information technology revolution has facilitated the use of applied statistics for risk measurement and management in banking. A second condition is an unstable macroeconomic environment, since the concomitant fluctuating asset prices are likely to spur risk-transfer innovations. Third, regulation can inhibit some innovations and encourage others (as a mechanism to avoid regulation) as consistent with Kane’s $(1981,2012)$ "regulatory dialectic”. For example, regulatory capital arbitrage - or the ability to hold a particular risk in a different form and receive regulatory capital relief for doing so - has been a key driver of U.S. mortgage securitization activity for two decades. Finally, taxes can spur financial innovations to the extent that they create incentives to repackage (or re-label) specific income streams so as to reduce tax liability. Over the past 30 years, each of the environmental conditions (1) - (5) that were noted above was markedly altered - resulting in substantial changes to the commercial banking industry.

Furthermore, as noted previously by Molyneux and Shamroukh (1999) and Frame and White (2004), there has been a surprising dearth of empirical studies that test hypotheses with respect to financial innovation in general. This is especially true for hypotheses that focus on the

\footnotetext{
${ }^{4}$ A similar perspective can be found in Smith (2013) and Ackerman (2013).
} 
structural conditions that encourage innovation. For example, Frame and White (2004) identified only two papers that tested hypotheses concerning structural conditions that encourage financial innovation (Ben-Horim and Silber, 1977; and Lerner, 2002), although Lerner (2006) has made a more recent contribution.

Instead, the comparatively few empirical studies that have been done tend to focus on the characteristics of users/adopters of innovations - sometimes on a cross-sectional basis and other times in the context of the diffusion of the innovation. In surveying the literature in preparation for this chapter, we find that more empirical studies have appeared, but the field is still relatively sparse, and the studies still focus largely on the characteristics of users/adopters. This finding represents a supplementary contribution of this chapter.

\section{Financial Innovation and Banking: 1980-2010}

In this section, we survey the literatures pertaining to several specific financial innovations that have appeared over the past 30 years or so that were specifically driven by technological change. We have organized our discussion along the lines of the three major categories that we described in Section 2: new products and services; new production processes; and new organizational forms.

\section{A1. Products}

Mortgage loans were one suite of products that experienced a great deal of change in the United States during the 25 years leading up to the financial crisis. In 1980, long-term fully amortizing fixed-rate mortgages were the norm; and this product was offered primarily by thrift institutions. Moreover, these loans required substantial down payments and a good credit history; 
and the accumulated equity was relatively illiquid.

These characteristics have markedly evolved. ${ }^{5}$ The first big change occurred in the early 1980s with the widespread introduction of various types of adjustable-rate mortgages (ARMs), which had previously been banned by federal regulators. The Tax Reform Act of 1986, which ended federal income tax deductions for non-mortgage consumer debt, spurred substantial growth in home equity lending. One mortgage innovation that is more directly tied to technological change is subprime lending, which was originally predicated on the use of statistics for better risk measurement and risk-based pricing to compensate for these higher risks. However, the subprime mortgage crisis has uncovered significant shortcomings in the underlying statistical models.

Subprime Mortgages. Subprime mortgage lending, broadly defined, relates to borrowers with poor credit histories (e.g., a FICO score below 620) and/or high leverage as measured by either debt/income (personal leverage) or loan-to-value (property leverage). Some analysts also may view certain mortgage characteristics (such as adjustable rates with near-term resets or prepayment penalties) as being subprime. Mortgages guaranteed by the Federal Housing Administration (FHA) are generally not considered subprime, although the borrower profiles are similar.

The subprime mortgage market grew rapidly in the U.S. during the first decade of the twenty-first century - averaging about $20 \%$ of residential mortgage originations between 2004 and 2006. At the end of 2006, subprime mortgages outstanding stood at $\$ 1.2$ trillion. Subprime mortgage lending then markedly receded in 2007 and virtually disappeared thereafter, as falling house prices led to a wave of subprime mortgage defaults (and associated foreclosures). By the end

\footnotetext{
${ }^{5}$ Gerardi, Rosen, and Willen (2012) provide an overview of the changes in the mortgage market since the 1970s and argue that these changes - especially mortgage securitization (which will be discussed below) - helped reduce imperfections in mortgage lending. To support this claim, the authors demonstrate that the links between future
} 
of 2012, subprime mortgages outstanding totaled only $\$ 475$ billion. Foote, Gerardi, Goette, and Willen (2008) and Mayer, Pence, and Sherlund (2009) provide excellent overviews of the subprime mortgage crisis.

Subprime mortgage lending acts to expand the pool of potential homeowners and helped to lead the U.S. to a record homeownership rate in 2004 of $69.2 \%$-- even in the face of declining housing affordability in many areas of the country. On the other hand, subprime mortgages typically come with more onerous terms, such as higher interest rates and prepayment penalties. This led to some concern that subprime lending can be "predatory" in nature, especially since lower-income and/or minority households are much more likely to have subprime mortgages. In the years leading up to the crisis, many state and local governments enacted predatory lending laws that restricted certain lending practices. Post-crisis, the Dodd-Frank Act created a new Consumer Financial Protection Bureau and required the regulator to establish the definition of a "qualified mortgage” (QM), which requires the lender to verify a borrower's ability to pay and to have limited up-front fees and points and forbids the lender from including contract features such as interest-only payments, negative amortization, balloon payments, and most prepayment penalties. Non-QMs face much higher legal risks if the borrower can demonstrate that the mortgage was originated without regard to the borrower's ability to repay.

Some research has sought to explain the existence and efficiency of the subprime mortgage market. Crews-Cutts and Van Order (2005) explain various stylized facts pertaining to subprime loan pricing and performance in the context of financial contracting theory. Chinloy and Macdonald (2005) discuss how the subprime market helps to complete the credit supply schedule

household incomes and current home purchases became substantially tighter between 1970 and 2001. 
and therefore enhance social welfare, while Nichols, Pennington-Cross, and Yezer (2005) explain why prime and subprime mortgage markets are distinct and not continuous. More recent research has focused on the importance of rising home prices in facilitating subprime mortgage financing (e.g., Goetzmann, Peng, and Yen, 2012; Bhardwaj and Sengupta, 2012; and Brueckner, Calem, and Nakamura 2012).

Other papers have documented the characteristics of subprime borrowers and mortgages. Lax, Manti, Raca, and Zorn (2004) find that, relative to prime borrowers, subprime borrowers are more likely to have poor credit, lower-incomes, less education, and belong to minority groups. Chomsisengphet and Pennington-Cross (2006) provide several stylized facts about subprime mortgage loans over time, including borrower credit quality, interest rates, down payment requirements, and the presence of prepayment penalties. Other papers look at the geographic distribution of subprime borrowers (Calem, Gillen, and Wachter, 2004; Mayer and Pence, 2008) and the incidence of subprime mortgage features (Farris and Richardson, 2004; Rose, 2013). Finally, there are a number of papers that study how local predatory lending laws affect subprime mortgage credit supply: Elliehausen and Staten, (2004); Harvey and Nigro, (2003, 2004); Quercia, Stegman, and Davis, (2004); and Ho and Pennington-Cross, (2006a).

Another strand of research studied subprime loan termination by jointly estimating empirical models of prepayment and default (e.g., Alexander, Grimshaw, McQueen, and Slade 2002; Pennington-Cross 2003; Danis and Pennington-Cross 2005; Ho and Pennington-Cross 2006b, 2010; and Pennington-Cross and Chomsisengphet 2007). Related papers have sought to explain the length of time between delinquency and default (Danis and Pennington-Cross 2008); time in foreclosure (Pennington-Cross 2006; Capozza and Thomson 2006; Pennington-Cross 
2010); and loss given default (Capozza and Thomson 2005).

Since the onset of the subprime mortgage crisis, research has attempted to identify various sources of the problem. Mayer, Pence, and Sherlund (2009) and Gerardi, Lehnert, Sherlund, and Willen (2008) among others point to a significant increase in borrower leverage during the mid2000s, as measured by combined loan-to-value (CLTV) ratios, which was soon followed by falling house prices. ${ }^{6}$ CLTV is important because economic theory predicts that borrowers with positive home equity will not default. That is, distressed borrowers with positive equity could borrow against this equity or simply sell the home and pocket any net proceeds. Hence, negative equity (owing more than the home is worth) is a necessary condition for mortgage default (see, for example, Foote, Gerardi, and Willen, 2008). As U.S. house prices declined in many parts of the U.S. during 2007 and 2008, an increasing number of homeowners found themselves with negative equity in their homes. Many borrowers facing negative income shocks - especially financially fragile subprime mortgage borrowers - subsequently defaulted on their loans.

But how did such financially fragile borrowers obtain mortgage financing in the first place? Some research attention has been paid to the evolution of subprime mortgage underwriting standards. In particular, the focus has been on declining underwriting standards as measured by observable characteristics (e.g., Gerardi, Lehnert, Sherlund, and Willen, 2008; Mayer, Pence, and Sherlund, 2009) or by increased forecast errors from empirical default models (Demyanyk and Van Hemert, 2011; An, Deng, Rosenblatt, and Yao, 2012). The declining underwriting standards likely emanated from the sizeable rise in U.S. house prices between 2001 and 2006, which likely masked

\footnotetext{
${ }^{6}$ Unfortunately, only the loan-to-value ratio of the first lien mortgage at origination is typically observed in commercially available mortgage data. Second mortgages, such as home equity loans and home equity lines of credit, were unreported and became increasingly popular in the U.S. during the housing boom.
} 
much of the weakness.

\section{A2. Services}

Recent service innovations primarily relate to enhanced account access and new methods of payment - each of which better meets consumer demands for convenience and ease. ${ }^{7}$ Automated teller machines (ATMs), which were introduced in the early 1970s and diffused rapidly through the 1980s, significantly enhanced retail bank account access and value by providing customers with around-the-clock access to funds. ATM cards were then largely replaced through the 1980s and 1990s by debit cards, which bundle ATM access with the ability to make payment from a bank account at the point-of-sale. Over the past two decades, remote access has migrated from the telephone to the personal computer and most recently to the mobile smart phone. Online banking, which allows customers to monitor accounts and originate payments using "electronic bill payment,” is now widely used. Stored-value, or prepaid, cards have also become ubiquitous. ${ }^{8}$

Debit Cards. Debit cards are essentially “pay-now” instruments linked to a checking account whereby transactions can happen either instantaneously using online (PIN-based) methods or in the near future with offline (signature based) methods. Consumers typically have the choice of using online or offline methods, and their selection often hinges on the respective benefits: Online debit allows the cardholder also to withdraw cash at the point-of-sale, and offline provides float. According to ATM \& Debit News, there were approximately 40.8 billion debit transactions

\footnotetext{
${ }^{7}$ The discussion in this section complements the overview that is found in the companion chapter ("Payments and Payment Systems”) by David Humphrey in this volume.

${ }^{8}$ Other small-dollar payment options have emerged in recent years, such as smart cards and PayPal. However, we do not discuss these further due to their limited penetration and a dearth of research relating to "electronic cash.”
} 
in the U.S. during 2012 that totaled almost $\$ 1.6$ trillion.

Much of the research that pertains to debit cards relates to identifying the most likely users of this payment instrument. Such demand-side explorations have been conducted individually as well as jointly across multiple payment options. Stavins (2001), for example, uses data from the 1998 Survey of Consumer Finances (SCF) and finds that debit usage is positively related to educational attainment, homeownership status, marital status, business ownership, and being a white collar worker; and is negatively related to age and net worth. Klee (2006) extends this analysis to consider the 1995, 1998, and 2001 SCFs and reports a secular increase in adoption driven by similar demographic factors. ${ }^{9}$ Additional U.S. evidence is provided by: Mantel and McHugh (2001), who use survey data from Vantis International; by Hayashi and Klee (2003), who use data from a 2001 survey conducted by Dove Consulting; as well as by Borzekowski and Kiser (2008) and Borzekowski, Kiser, and Ahmed (2008), who use 2004 data from the Michigan Surveys of Consumers.

Some additional analysis by Hayashi and Klee (2003) studied the circumstances under which consumers are likely to use debit cards and found that these are more often used at grocery stores and gas stations than at restaurants. Related to this, the authors also find that debit card usage is positively related to the incidence of self-service transactions.

Online Banking. As households and firms rapidly adopted Internet access during the late1990s, commercial banks established an online presence. According to DeYoung (2005), the first bank websites were launched in 1995; and by 2002 nearly one-half of all U.S. banks and thrifts

\footnotetext{
${ }^{9}$ See also Anguelov, Hilgert, and Hogarth (2004) for the relevant statistics that pertain to these surveys. Also, using data across four SCFs, Zinman (2009) reports that, other things being equal, the choice of using debit cards is positively related to being a "revolver" of credit card balances (as opposed to paying off such balances each month).
} 
operated transactional websites. As of 2012, bank call report data suggests that 90.0 percent of commercial banks offer transactional websites (and these banks control 95.3percent of commercial bank deposits).

The primary line of research that relates to online banking has been aimed at understanding the determinants of bank adoption and how the technology has affected bank performance. In terms of online adoption, Furst, Lang, and Nolle (2002) find that U.S. national banks (by the end of the third quarter of 1999) were more likely to offer transactional websites if they were: larger, younger, affiliated with a holding company, located in an urban area, and had higher fixed expenses and non-interest income. Sullivan (2000) and Courchane, Nickerson, and Sullivan (2002), who use smaller samples, present evidence that is consistent with these findings.

Similar analysis is provided by Hernandez-Murillo, Llobet, and Fuentes (2010), who look at Internet banking adoption at U.S. banks during the mid-2000s. These authors confirm many of the previous findings, but also that transactional website adoption is positively related to countylevel demographics (median household income, education, Internet access) and market concentration and negatively related to additional bank characteristics (branching intensity, ratio of capital-to-total assets, and nonperforming loans). Further, Dow (2007) analyzes data for U.S. credit unions and finds that online banking adoption is related to institution size and having a lower proportion of nonperforming loans. On the flip side, Goddard, McKillop, and Wilson $(2008,2009)$ find that credit unions that do not provide transactional websites are more likely to fail and/or be acquired.

With respect to online bank performance, DeYoung, Lang, and Nolle (2007) report that Internet adoption improved U.S. community bank profitability - primarily through deposit-related 
charges. In a related study, Hernando and Nieto (2007) find that, over time, online banking was associated with lower costs and higher profitability for a sample of Spanish banks. Both papers conclude that the Internet channel is a complement to - rather than a substitute for - physical bank branches. Additional evidence is offered by Ciciretti, Hasan, and Zazzara (2009), who also find that Italian banks that offered Internet-related services had higher profitability (and stock returns) relative to their peers. However, a contemporaneous study of U.S. credit unions found no relationship between online banking adoption and profitability, but did find significantly higher operating expenses (Dandapani, Karels, and Lawrence, 2008).

Other studies look at the demand-side for online banking services. Mantel (2000) studies the demographic characteristics of users of electronic/online bill payment. Among other things, the author finds that electronic bill payers tend to be: older, female, higher income, and homeowners. Bauer and Hein (2006), who analyze data from the Survey of Consumer Finances, find that younger customers and those with previous experience with remote banking technologies are more likely to use online banking.

Prepaid Cards. As the name implies, prepaid cards are instruments whereby cardholders "pay early" and set aside funds in advance for future purchases of goods and services. (By contrast, debit cards are "pay-now", and credit cards are "pay later".) The monetary value of the prepaid card resides either on the card or at a remote database.

Prepaid cards can be generally delineated as either "closed” systems (e.g., a retailer-specific gift card, such as a card for Macy's or Best Buy) or "open” systems (e.g., a payment-network branded card, such as Visa or MasterCard). Closed-system prepaid cards have also been effective as a cash substitute on university campuses, as well as for mass transit systems and retailers. Open- 
card systems, while less effective in some of these contexts to date, may ultimately have greater promise owing to their wider functionality, which more resembles traditional debit and credit cards. For example, these prepaid cards can be used to withdraw money from an ATM and to make purchases or pay bills in person, over the phone, or online. Cheney and Rhine (2006) discuss two types of open-system prepaid programs - payroll cards and general spending reloadable cards each of which provides functions that are similar to deposit accounts. Payroll cards, which were first introduced in 2001, are particularly attractive for unbanked workers and their employers because of lower transactions costs (McGrath 2005). Such cards have also been used to deliver welfare benefits and disaster relief. Reloadable cards, which are typically offered through grocery stores and convenience stores, have most often been promoted to immigrants for remittances, to travelers, or to parents for teen purchases. Wilshusen, Hunt, van Opstal, and Schneider (2012) use transactions-level data to summarize consumers' use of prepaid cards.

Some descriptive research on prepaid cards is focused on certain public policy issues that are related to this payments medium. Furletti and Smith (2005) note the lack of state and federal consumer protections, but mention that card associations and bank-issuers have voluntarily extended some safeguards in practice, such as "zero liability" and "charge-back" provisions. Keitel (2008) looks more broadly at consumer protections for prepaid gift cards by studying state statutes and Federal Trade Commission rulings. Sienkiewicz (2007) discusses the potential for prepaid cards to be used in money laundering schemes. The author notes instances with offshore card issuance and the ability to access cash at ATMs as being the most vulnerable to illicit activity.

\section{B. Production Processes}

The past 30 years have witnessed important changes in banks' production processes. The 
use of electronic transmission of bank-to-bank retail payments, which had modest beginnings in the 1970s, has exploded owing to greater retail acceptance, online banking, and check conversion. In terms of intermediation, there has been a steady movement toward a reliance on statistical models. For example, credit scoring has been increasingly used to substitute for manual underwriting - and has been extended even into relationship-oriented products, such as small business loans. Similar credit risk measurement models are also used when creating structured financial products through "securitization". Statistical modeling has also become central in the overall risk management processes at banks through portfolio stress testing and value-at-risk models - each of which is geared primarily to evaluating portfolio value in the face of significant changes in macro-financial environments.

Automated Clearinghouse (ACH). An automated clearinghouse (ACH) is an electronic funds transfer network that connects banks and is primarily used for recurring, small-dollar payments. While several ACH networks emerged in the 1970s, volumes grew only modestly through the 1980s, with the networks' being used almost exclusively for direct payroll deposits. Over the past 20 years, however, consolidation has occurred, and volumes have soared. According to the National Automated Clearing House Association, the number of ACH payments has increased from just under 2 billion in 1991 to 21 billion in 2012. (Over the same timeframe, the dollar value of ACH items transmitted rose from $\$ 6.9$ trillion to $\$ 36.9$ trillion.) These payments, in turn, are now made through only two ACH networks: the New York Clearinghouse's Electronic Payments Network, and the Federal Reserve System's FedACH.

The modest literature on ACH networks has been aimed at understanding supply and demand conditions in support of FedACH pricing policies. Bauer and Hancock (1995) found that 
over the 1979-1994 period the cost of processing an ACH item fell dramatically owing to scale economies, technological change, and lower input prices. Using a much smaller sample, Bauer and Ferrier (1996) also found support for the existence of ACH scale economies as well as significant allocative inefficiencies. Stavins and Bauer (1999), on the other hand, estimated ACH demand elasticities by exploiting FedACH price changes over time - finding ACH demand to be highly inelastic.

The two most recent papers studied network externalities for ACH. Gowrisankaran and Stavins (2004) find support for significant network externalities, which they ascribe to technological advancement, peer-group effects, economies of scale, and market power. Ackerberg and Gowrisankaran (2006) identify large fixed costs of bank adoption as the barrier to greater use of ACH transactions and thus to society's capturing the accompanying potential cost savings.

Small Business Credit Scoring. Banks use a number of different lending technologies to lend to informationally opaque small businesses (for a summary of these technologies, see Berger and Udell, 2006). One new technology that was introduced in the 1990s and continues to evolve is small business credit scoring (SBCS). This technology involves analyzing consumer data about the owner of the firm and combining it with relatively limited data about the firm itself using statistical methods to predict future credit performance. Credit scores had long been pervasive in consumer credit markets (e.g., mortgages, credit cards, and automobile credits) - and resulted in widely available, low-cost, commoditized credits that are often packaged and sold into secondary markets.

The empirical literature that has studied SBCS has focused on the determinants of bank adoption and diffusion of this technology, as well as on how SBCS has affected credit 
availability. Two studies have statistically examined the determinants of the probability and timing of large U.S. banks' adoption of SBCS. Frame, Srinivasan, and Woosley (2001) and Akhavein, Frame, and White (2005) both find an important role for size and organizational structure in the adoption decision: Larger banking organizations with fewer bank charters and more bank branches were more likely to adopt and also to adopt sooner. This suggests that large banks with a more "centralized" structure were more likely to adopt SBCS. While the use of the SBCS technology still appears to be mostly limited to large banking organizations, one recent study suggests that small banks now often make use of the consumer credit score of the principal owner of the firm (Berger, Cowan, and Frame, 2007).

Several studies have focused on the relationship between SBCS adoption and credit availability. Three studies documented increases in the quantity of lending (Frame, Srinivasan, and Woosley, 2001; Frame, Padhi, and Woosley, 2004; Berger, Frame, and Miller, 2005). One found evidence that is consistent with more lending to relatively opaque, risky borrowers (Berger, Frame, and Miller, 2005); another with increased lending within low-income as well as high-income areas (Frame, Padhi, and Woosley, 2004); and another with lending over greater distances (DeYoung, Frame, Glennon, and Nigro, 2011). In instances in which SBCS is used in conjunction with other lending technologies to reduce information asymmetries, it is also shown to result in increased loan maturity (Berger, Espinosa-Vega, Frame, and Miller, 2005) and reduced collateral requirements (Berger, Espinosa-Vega, Frame, and Miller, 2011).

Asset Securitization. Asset securitization refers to the process by which nontraded assets 
are transformed into tradable "asset-backed securities" (ABS) by repackaging cashflows. ${ }^{10}$ Today, in the U.S., securitization is widely used by large originators of retail credit - specifically mortgages, credit cards, and automobile loans. As of year-end 2012, federally sponsored mortgage pools and privately arranged ABS issues (including private-label mortgage-backed securities) totaled almost $\$ 8.0$ trillion of the $\$ 56.9$ trillion in U.S. credit market debt outstanding

A large number of books and articles have been devoted to the process of securitization and the analytics required to structure and value the resulting assets. As a result, we provide only a cursory review of the issues. Generally speaking, asset securitization involves several steps. The first is the sale of a pool of financial assets to a legally separate ("bankruptcy remote”) trust against which liabilities (the ABS) are issued. ${ }^{11}$ In this way, the original holder of the assets receives a cash payment, thereby liquefying its position. However, since the seller presumably has better information about the assets than does the buyer of the ABS (who thus faces the potential for "adverse selection"), the buyer requires some form of "credit enhancement" in the form of third-party guarantees, overcollateralization, or the creation of subordinate claims through "tranching". ${ }^{12}$ While the first two forms of credit enhancement are straightforward, the

\footnotetext{
10 The Government National Mortgage Association (“Ginnie Mae”) was the first "modern” issuer of ABS residential mortgage-backed securities (RMBS) - in 1970. The Federal Home Loan Mortgage Corporation ("Freddie Mac") was a "fast second", with its RMBS appearing in 1971. As Goetzmann and Newman (2010) have documented, commercial mortgages were securitized at least as early as the 1920s, and some of these commercial mortgages appear to have included multi-family (i.e., apartment) residential structures; see also Snowden (2010a). And a form of securitization appears to have been attempted for farm mortgages in the late $19^{\text {th }}$ century (Snowden 2010b).

${ }^{11}$ This discussion implicitly assumes a "liquidating pool" of assets with fixed (but prepayable) terms to maturity. Some assets, like credit cards, are placed into "revolving pools," which allow for the ex post addition of assets, since these loans have no fixed payment amount or term.

${ }^{12}$ Investors may also believe that deal sponsors are additionally providing some level of implicit recourse as a method to maintain their reputation in the market. Higgins and Mason (2004) and Gorton and Souleles (2005) provide empirical evidence consistent with this conjecture - higher-rated sponsors execute ABS deals at tighter spreads.
} 
last one requires some explanation.

Tranching involves the creation of two or more security types that are defined by their priority of claims. ${ }^{13}$ The original seller often retains the most junior (“equity”) security -- the one with the lowest payment priority (and thus the first absorption of losses) - as a way of assuaging skeptical investors about the quality of the assets in the pool. ${ }^{14}$ However, sophisticated investors - such as hedge funds - sometimes also purchase and hold such positions. ${ }^{15}$

In addition to providing liquidity, securitization may be socially beneficial insofar as it allows for lower-cost financing of loans: Efficiencies from greater specialization can arise when (through securitization) origination, funding, and servicing are separated (as compared with the “traditional” vertically integrated structure of these functions within a depository institution); also, the separation of funding allows a wider array of investors to access mortgage payment streams more directly, rather than being confined to indirect access through deposits or other investments in depository institutions. In addition, securitization may also hold private benefits for depository institutions that seek to manage their required capital positions. ${ }^{16}$ Thomas (2001) presents empirical evidence that the stockholders of certain ABS issuers benefit from securitization - i.e., first-time issuers, large issuers, frequent issuers, lower-quality issuers, and

\footnotetext{
13 The case of two securities (senior and junior) is generally sufficient to make the stylized points about securitization, but in practice much more granular structures are observed.

14 This is consistent with important theoretical work in financial economics by Leland and Pyle (1977) and Myers and Majluf (1984) that is related to capital structure more generally. See DeMarzo and Duffie (1999) and DeMarzo (2005) for similar discussions that are specific to asset-backed securities.

${ }^{15}$ Boot and Thakor (1993) and Plantin (2004) provide theoretical explanations for the sale of tranched securities to investors of differing financial sophistication.

${ }^{16}$ For example, as Frame and White (2005) and others have demonstrated, the ability of banks bound by risk-based capital requirements to swap residential mortgages (on which there is a risk-based capital requirement of 4\%) for the mortgage-backed securities (MBS) that are issued and guaranteed by Fannie Mae or Freddie Mac (on which there is a risk-based capital requirement of only 1.6\%) and that contain exactly the same mortgages provides the banks with a “regulatory capital arbitrage” (RCA). See Jones (2000) for a more general discussion of the RCA phenomenon.
} 
bank-issuers. $^{17}$

Some analysts have pointed to incentive conflicts inherent in securitization as a key reason for the magnification of the recent financial crisis. Ashcraft and Schuermann (2008) identify seven key informational frictions that arise in the subprime securitization model; discuss how market participants work to minimize such frictions; and speculate as to how this process broke down. One particular conflict was that of mortgage originators' no longer routinely holding equity tranches of their securitizations and hence having little "skin-in-the-game”. The Dodd-Frank Wall Street Reform and Consumer Protection Act of 2010 now requires that loan originators hold five percent of their securitization deals (in one form or another). The law includes a carve-out exception for “qualified residential mortgages", which are meant to be extremely safe (i.e., lowrisk) mortgages but which (ironically) regulators have subsequently proposed to define as encompassing almost the entire mortgage market.

Risk Management. Advances in information technology (both hardware and software) and financial theory spurred a revolution in bank risk management over the past two decades. Two popular approaches to measuring and managing financial risks are stress-testing and value-at-risk (VaR). In either case, the idea is to identify the level of capital required for the bank to remain solvent in the face of unlikely adverse environments.

Stress testing involves the construction of adverse scenarios for credit and/or interest rate conditions and then the valuation of assets and liabilities - and thus solvency - under these stressed

\footnotetext{
${ }^{17}$ Prior empirical work by Lockwood, Rutherford, and Herrera (1996) and Thomas (1999) had used subsamples of the data and had found conflicting evidence: The former paper focused on 1985 to 1992 and the latter paper on 1991 to 1996.
} 
circumstances. ${ }^{18}$ These tests can be conducted assuming either one or multiple periods. Fender and Gibson (2001) provide a pre-crisis survey of stress-testing in financial institutions.

Stress tests have become increasingly important following the recent financial crisis and the formal adoption of these methods by bank supervisory authorities around the world. In the U.S., stress tests are carried out as part of the Federal Reserve's annual “Comprehensive Capital Assessment Review" for its largest banking organizations. These stress tests involve the creation of hypothetical near-term macroeconomic scenarios, which are then used by banking organizations as inputs into their risk measurement models to produce estimates of credit losses, income, expenses, and capital under stress. The resulting capital estimates, in turn, act as the basis for each institution's capital plan, which is required to be submitted annually to the Federal Reserve. Concurrently, the Federal Reserve applies the same macroeconomic projections to its own risk measurement models to produce independent supervisory estimates of required capital for each banking organization. These supervisory estimates, along with a qualitative assessment of the quality of the banking organization's own capital planning process, are used as the basis for evaluating the capital plan submissions.

As stress testing has recently become a critical risk management tool for both financial institutions and their regulators, research should be aimed at better understanding stress test limitations and offering improvements for current practice. Pre-crisis analysis by Berkowitz (19992000) and Kupiec (2000) both discuss certain shortcomings of stress testing for risk management, including whether the results of such tests will generally achieve equity capital allocations that are

\footnotetext{
${ }^{18}$ Related stress-testing procedures are also used by some central banks as a method of evaluating financial system resiliency in the face of shocks. See, for example, Cihak (2007), Goodhart (2006), Elsinger, Lehar, and Summer (2006), and Majnoni, Martinez-Peria, Blaschke, and Jones (2001).
} 
sufficient to stave-off default under duress. More recently, research has considered the use of empirical likelihood to generate macroeconomic scenarios (Glasserman, Kang, and Kang, 2012) and the need to expand the set of scenarios to other banking-sector shocks (Pritsker, 2012). Acharya, Engle, and Pierret (2013) compare capital requirements suggested by stress tests using market data to outcomes reported by U.S. and European regulators and note deficiencies related to regulatory risk weights. Frame, Gerardi, and Willen (2013) analyze how the risk-based capital stress test for Fannie Mae and Freddie Mac failed to warn regulators of massive impending losses. Research is also being aimed at understanding the implications of the breadth and depth of supervisory disclosures - both in terms of the supervisory models and parameters ex ante (e.g., Frame, Gerardi, and Willen, 2013) and stress test results ex post (e.g., Goldstein and Sapra, 2012; Leitner and Goldstein, 2013).

VaR relies on a probabilistic approach that evaluates the return distributions of assets. In this case, a bank would define a probability level of the return distribution (e.g., 99.9\%) as an outer limit of exposure and then calculate the economic losses that are associated with that point on the distribution. Because of the focus on return distributions, VaR has been applied most widely to trading portfolios, which are populated by readily marketable securities. Nevertheless, the principles involved have also been applied to credit portfolios more generally. A large number of books and articles have been devoted to $\mathrm{VaR}$ - primarily centered on the appropriate characterization of return distributions for various assets and the use of VaR principles in the Basel II Capital Accord.

\section{Organizational Forms}

New bank organizational forms have emerged in the United States over the past few 
decades. Securities affiliates (so-called "Section 20" subsidiaries or the creation of "financial holding companies”) for very large banks and Subchapter S status for very small banks, were the byproduct of regulatory/legal evolution. ${ }^{19}$ Indeed, only one new organizational form, the Internetonly (or Internet-primary) bank, arose from technological change. These institutions, which quickly emerged and disappeared, may represent an interesting laboratory for the study of "failed" financial innovations. We believe that understanding such experimental failures may hold important insights for understanding the keys to successful financial innovations.

The dramatic increase in individuals' use of the Internet in the 1990s created the possibility of a new organizational form in banking: the Internet-only (Internet-primary) bank. According to Delgado, Hernando, and Nieto (2007), as of mid-year 2002, there were some 35 Internet-only banks operating in Europe and another 20 in the U.S. However, in Europe, virtually all of these banks were affiliated with existing institutions, while in the U.S. they tended to be de novo operations. This may explain why most/all of the U.S. Internet-only banks have disappeared (through acquisition, liquidation, or closure) or established a physical presence to supplement their Internet base. This suggests that the dominant technology is one of "clicks and mortar.”

DeYoung (2001, 2005) finds that, as compared with conventional de novo banks, the Internet de novo banks are less profitable due to low business volumes (fewer deposits and lower

\footnotetext{
${ }^{19}$ Another important, but short-lived, organizational innovation driven by regulation was the "structured investment vehicle" (SIV). This was an entity sponsored by a large financial institution that typically held relatively long-term assets and issued relatively short-term liabilities and held little or no capital (but with some understanding that the sponsor would provide liquidity or capital infusions, if necessary. Many SIVs became distressed during the financial crisis and were repatriated onto sponsor balance sheets. Contemporaneous changes to accounting standards forced remaining entities to be consolidated. See Acharya, Schnabl, and Suarez (2013) for an analysis of SIV performance during the crisis.
} 
non-interest income) and high labor expenditures. However, the author also reports that the financial performance gaps narrow quickly over time due to scale effects. Relatedly, Cyree, Delcoure, and Dickens (2009) find that Internet-primary banks are larger and have lower net interest margins and loan losses. While the authors also find these institutions to be less profitable, they do find them to be more profit efficient (as measured by the distance from a bestpractice frontier that involves outputs and inputs). Delgado, Hernando, and Nieto (2007) similarly find that European Internet banks demonstrate technology-based scale economies.

\section{Conclusions}

This chapter has reviewed the literature on technological change and financial innovation in banking since 1980. This quarter century has been a period of substantial change in terms of bank services and production technologies, but much less so with respect to organizational form. As this survey indicates, although much has been learned about the characteristics of users and adopters of financial innovations and the attendant welfare implications, we still know little about how and why financial innovations are initially developed. This remains an important area for further research. 


\section{References}

Acharya, V. Engle, R. and Pierret, D. (2013). 'Testing macroprudential stress tests: The risk of regulatory risk weights', Available at: http://papers.ssrn.com/sol3/papers.cfm?abstract_id=2254221.

Acharya, V., Schnabl P., and Suarez G. (2013). 'Securitization without risk transfer', Journal of Financial Economics, 107(3): 515-536.

Ackerberg, D.A. and Gowrisankaran, G. (2006). 'Quantifying equilibrium network externalities in the ACH banking industry’, RAND Journal of Economics, 37(3): 738-761.

Ackermann, J. (2013). 'Financial innovation: Balancing private and public interests', in Financial Innovation: Too Much or Too Little? M. Haliassos (ed.), Cambridge, MA: MIT Press, 213-230.

Akhavein, J., Frame, W.S. and White, L.J. (2005). 'The diffusion of financial innovation: An examination of the adoption of small business credit scoring by large banking organizations', Journal of Business, 78(2): 577-596.

Alexander, W.P., Grimshaw, S.D., McQueen, G.R. and Slade, B.A. (2002). 'Some loans are more equal than others: Third-party originations and defaults in the subprime mortgage industry', Real Estate Economics, 30(4): 667-697.

Allen, F. (2012). 'Trends in Financial Innovation and their welfare impact: An overview', European Financial Management, 18(4): 493-514.

An, X., Deng, Y., Rosenblatt, E., and Yao, V. (2012). 'Model stability and the subprime mortgage crisis’, Journal of Real Estate Finance and Economics, 45(3): 545-568.

Anguelov, C.E., Hilgert, M.A. and Hogarth, J.M. (2004). 'U.S. consumers and electronic banking, 1995-2003’, Federal Reserve Bulletin, 90(1): 1-18.

Ashcraft, A.B. and Schuermann, T. (2008). 'Understanding the securitization of subprime mortgage credit', Federal Reserve Bank of New York Staff Study \#318.

Bauer, K. and Hein, S. (2006). 'The effect of heterogeneous risk on the early adoption of Internet banking technologies', Journal of Banking \& Finance, 20(6): 1713-1725.

Bauer, P.W. and Ferrier, G.D. (1996). 'Scale economies, cost efficiencies, and technological change in Federal Reserve payment processing', Journal of Money, Credit, and Banking, 28(4): 1004-1039.

Bauer, P.W. and Hancock, D. (1995). 'Scale economies and technological change in Federal 
Reserve ACH payment processing', Economic Review, Federal Reserve Bank of Cleveland, Third Quarter: 14-29.

Beck, T., Chen, T., Lin, C. and Song, F.M. (2012). 'Financial innovation: The bright and the dark sides', SSRN Working Paper; available at:

http://papers.ssrn.com/sol3/papers.cfm?abstract_id=1991216.

Ben-Horim, M. and Silber, W.L. (1977). 'Financial innovation: A linear programming approach', Journal of Banking \& Finance, 1(3): 277-296.

Berger, A.N. (2003). 'The economic effects of technological progress: Evidence from the banking industry', Journal of Money, Credit, and Banking, 35(2): 141-176.

Berger, A.N., Cowan, A. and Frame, W.S. (2007). 'The surprising use of credit scoring in small business lending by 'community banks' and the attendant effects on credit availability, risk, and profitability’. Journal of Financial Services Research, 39(1): 1-17.

Berger, A.N., Espinosa-Vega, M., Frame, W.S. and Miller, N. (2005). 'Debt maturity, risk, and asymmetric information', Journal of Finance, 60(6): 2895-2923.

Berger, A.N., Espinosa-Vega, M., W.S. Frame, and Miller, N. (2011). 'Why do borrowers pledge collateral? New empirical evidence on the role of asymmetric information', Journal of Financial Intermediation, 20: 55-70.

Berger, A.N., Frame, W.S. and Miller, N. (2005). 'Credit scoring and the availability, price, and risk of small business credit’, Journal of Money, Credit, and Banking, 37(2): 191-222.

Berger, A.N., Kashyap, A.K. and Scalise, J.M. (1995). 'The transformation of the U.S. banking industry: What a long, strange trip it's been', Brookings Papers on Economic Activity, 2: 55-218.

Berger, A.N. and Udell, G.F. (2006). 'A more complete conceptual framework for SME finance', Journal of Banking \& Finance, 30(11): 2945-2966.

Berkowitz, J. (1999-2000). ‘A coherent framework for stress testing’, Journal of Risk, 2(2): 5-15.

Bhardwaj, G. and Sengupta, R. (2012). 'Subprime mortgage design', Journal of Banking \& Finance, 36(5): 1503-1519.

Boot, A.W.A. and Thakor, A.V. (1993). 'Security design’, Journal of Finance, 48(4): 1349-1378.

Borzekowski, R. and Kiser, E. (2008). 'The choice at the checkout: Quantifying demand across payment instruments’, International Journal of Industrial Organization, 26(4): 889-902. 
Borzekowski, R., Kiser, E., and Ahmed, S. (2008). 'Consumers' use of debit cards: Patterns, preferences, and price response', Journal of Money, Credit, and Banking, 40(1): 149-172.

Brueckner, J.K., Calem, P.S., and Nakamura, L.I. (2012). 'Subprime mortgages and the housing bubble', Journal of Urban Economics, 71(2): 230-243.

Calem, P.S., Gillen, K. and Wachter, S. (2004). ,The neighborhood distribution of subprime mortgage lending', Journal of Real Estate Finance and Economics, 29(4): 393-410.

Campbell, Tim S. (1988). Money and Capital Markets. Glenview, IL: Scott, Foresman.

Capozza, D.R. and Thomson, T.A. (2005). 'Optimal stopping and losses on subprime mortgages’, Journal of Real Estate Finance and Economics, 30(2): 115-131.

Capozza, D.R. and Thomson, T.A. (2006). 'Subprime transitions: Lingering or malignant in default? Journal of Real Estate Finance and Economics, 33(3): 241-258.

Cheney, J.S. and Rhine, S.L.W. (2006). 'Prepaid cards: An important innovation in financial services’, Federal Reserve Bank of Philadelphia Payment Card Discussion Paper 06-07.

Chinloy, P. and Macdonald, N. (2005). 'Subprime lenders and mortgage market completion', Journal of Real Estate Finance and Economics, 30(2): 153-165.

Chomsisengphet, S. and Pennington-Cross, A. (2006). 'The evolution of the subprime mortgage market', Review, Federal Reserve Bank of St. Louis, 88(1): 31-56.

Ciciretti, R., Hasan, I. and Zazzara, C. (2007). 'Do Internet activities add value? Evidence from traditional banks’, Journal of Financial Services Research, 35(1): 81-98.

Cihak, M. (2007). 'Introduction to applied stress testing’, IMF Working Paper \#07/59.

Cohen, W.M. (1995). 'Empirical studies of innovative activity', in Handbook of the Economics of Innovation and Technological Change. Paul Stoneman (ed.), Cambridge: Blackwell, 182-264.

Cohen, W.M. and Levin, R.C. (1989). 'Empirical studies of innovation and market structure', in Handbook of Industrial Organization, Vol. 2. Richard Schmalensee and Robert Willig (eds.), Amsterdam: North-Holland, 1059-1107.

Courchane, M., Nickerson D., and Sullivan R., (2002). 'Investment in Internet banking as a real option: Theory and tests’, Journal of Multinational Financial Management, 12(4): 347-363.

Crews-Cutts, A. and Van Order, R. (2005). 'On the economics of subprime lending', Journal of Real Estate Finance and Economics, 30(2): 167-196. 
Cyree, K.B., Delcoure, N. and Dickens, R. (2009). 'An examination of the performance and prospects for the future of Internet-primary banks'. Journal of Economics \& Finance, 33(2): 128147.

Dandapani, K., Karels, G.V., and Lawrence E.R. (2008). 'Internet banking services and credit union performance', Managerial Finance, 34(6): 437-446.

Danis, M.A. and Pennington-Cross, A. (2005). 'A dynamic look at subprime loan performance', Journal of Fixed Income, 15(1): 28-39.

Danis, M.A. and Pennington-Cross, A. (2008). 'The delinquency of subprime mortgages', Journal of Economics and Business, 60(1-2): 67-90.

Delgado, J., Hernando, I, and Nieto, M.J. (2007). 'Do European primarily Internet banks show scale and experience efficiencies?’, European Financial Management, 13(4): 643-671.

DeMarzo, P.M. (2005). 'The pooling and tranching of securities: A model of informed intermediation', Review of Financial Studies, 18(1): 1-35.

DeMarzo, P. and Duffie, D. (1999). 'A liquidity-based model of security design', Econometrica, 67(1): 65-99.

Demyanyk, Y. and Van Hemert, O. (2011). 'Understanding the subprime mortgage crisis', Review of Financial Studies, 24(6), 1848-1880.

DeYoung, R. (2001). 'The financial performance of pure play Internet banks', Economic Perspectives, Federal Reserve Bank of Chicago, 25: 60-75.

DeYoung, R. (2005). 'The performance of Internet-based business models: evidence from the banking industry', Journal of Business, 78(3): 893-947.

DeYoung, R., Lang, W.W. and Nolle, D.L. (2007). 'How the Internet affects output and performance at community banks’, Journal of Banking \& Finance, 31(4): 1033-1060.

DeYoung, R., Frame, W.S., Glennon, D. and Nigro, P., (2011). 'The information revolution and small business lending: The missing evidence', Journal of Financial Services Research, 39(1): 19-33.

Dow, J.P. (2007). 'The adoption of web banking at credit unions', The Quarterly Review of Economics and Finance, 47(3): 435-448.

Elliehausen, G. and Staten, M.E. (2004). 'Regulation of subprime mortgage products: An analysis 
of North Carolina's predatory lending law', Journal of Real Estate Finance and Economics, 29(4): 411-433.

Elslinger, H., Lehar, A., and Summer, M. (2006). 'Using market information for banking system risk assessment', International Journal of Central Banking, 2(1): 137-165.

Farris, J. and Richardson, C.A. (2004). 'The geography of subprime mortgage prepayment penalty patterns', Housing Policy Debate, 15(3): 687-714.

Fender, I. and Gibson, M.S. (2001). 'Stress testing in practice: a survey of 43 major financial institutions’, BIS Quarterly Review, June: 58-62.

Foote, C.L. Gerardi, K., and Willen, P.S. (2008). 'Negative equity and foreclosure: Theory and evidence', Journal of Urban Economics, 64(2): 234-245.

Foote, C.L., Gerardi, K., Goette, L., and Willen P.S. (2008). 'Just the facts: An initial analysis of subprime's role in the housing crisis', Journal of Housing Economics, 17(4): 1-24.

Frame, W.S., Gerardi, K., and Willen, P.S. (2013). 'Supervisory stress tests, model risk, and model disclosure: Lessons from OFHEO, Federal Reserve Bank of Atlanta Working Paper.

Frame, W.S., Padhi, M. and Woolsey, L. (2004). 'The effect of credit scoring on small business lending in low- and moderate income areas’, Financial Review, 39(1): 35-54.

Frame, W.S., Srinivasan, A. and Woosley, L. (2001). 'The effect of credit scoring on small business lending', Journal of Money, Credit, and Banking, 33(3): 813-825.

Frame, W.S. and White, L.J. (2004). 'Empirical studies of financial innovation: Lots of talk, little action?' Journal of Economic Literature, 42(1): 116-144.

Frame, W.S. and White, L.J. (2005). 'Fussing and fuming over Fannie and Freddie: How much smoke, how much fire?’ Journal of Economic Perspectives, 19 (2): 159-184.

Furletti, M. and Smith, S. (2005). 'The laws, regulations, and industry practices that protect consumers who use electronic payment systems: ACH e-checks and prepaid cards', Federal Reserve Bank of Philadelphia Payment Card Discussion Paper \#05-04.

Furst, K., Lang, W. and Nolle, D. (2002). 'Internet banking', Journal of Financial Services Research, 22(1/2): 95-117.

Gennaioli, N., A Shleifer, and R.W. Vishny. (2012). 'Neglected risks, financial innovation, and financial fragility’, Journal of Financial Economics, 104(3): 452-468. 
Gerardi, K., Lehnert, A., Sherlund, S.M., and Willen, P.S. (2008). 'Making sense of the subprime mortgage crisis’, Brookings Papers on Economic Activity, 2008: 69-159.

Gerardi, K., Rosen, H.S., and Willen, P.S. (2012). 'The impact of deregulation and financial innovation on consumers: The case of the mortgage market', Journal of Finance, 65(1): 333-360.

Glasserman, P. Kang, C. and Kang, W. (2012). 'Stress scenario selection by empirical likelihood', Available at: http://papers.ssrn.com/sol3/papers.cfm?abstract_id=2101465.

Goddard, J., McKillop, D. and Wilson, J.O.S. (2008). 'Consolidation in the US Credit Union Sector: Determinants of Failure and Acquisition', SSRN Working Paper. Available at: http://papers.ssrn.com/sol3/papers.cfm?abstract_id=1200262.

Goddard, J., McKillop, D., Wilson, J.O.S. (2009). 'Which Credit Unions Are Acquired?’ Journal of Financial Services Research, 36(2-3): 231-252.

Goetzmann, W.N. and Newman, F. (2010). 'Securitization in the 1920s', NBER Working Paper \#15650. Available at: http://cid.bcrp.gob.pe/biblio/Papers/NBER/2010/enero/w15650.pdf.

Goetzmann, W.N., Peng, L., and Yen, J. (2012). 'The subprime crisis and house price appreciation', Journal of Real Estate Finance and Economics, 44(1-2): 36-66.

Goldstein, I. and Sapra, H. (2012). 'Should banks' stress test results be disclosed? An analysis of the costs and benefits', Chicago Booth Working Paper.

Goodhart, C.A.E. (2006). 'A framework for assessing financial stability?' Journal of Banking and Finance, 30(12): 3415-3422.

Gorton, G. and Souleles, N. (2005). 'Special purpose vehicles and securitization’, National Bureau of Economic Research Working Paper \#11190.

Gowrisankaran, G. and Stavins, J. (2004). 'Network externalities and technology adoption: Lessons from electronic payments’, RAND Journal of Economics, 35(2): 260-276.

Haliassos, M. (2013). Financial Innovation: Too Much or Too Little? Cambridge, MA: MIT Press.

Harvey, K.D. and Nigro, P.J. (2003). 'How do predatory lending laws influence mortgage lending in urban areas? A tale of two cities’, Journal of Real Estate Research, 25(4): 479-508.

Harvey, K.D. and Nigro, P.J. (2004). 'Do predatory lending laws influence mortgage lending? An analysis of the North Carolina predatory lending law, Journal of Real Estate Finance and Economics, 29(4): 435-456.' 
Hayashi, F. and Klee, E. (2003). 'Technology adoption and consumer payments: Evidence from survey data, Review of Network Economics, 2(2): 175-190.

Henderson, B.J. and N.D. Pearson. (2011). 'The dark side of financial innovation: A case study of the pricing of a retail financial product', Journal of Financial Economics, 100(2): 227-247.

Hernández-Murillo, R., G. Llobet, and R. Fuentes. (2010). 'Strategic online banking adoption', Journal of Banking \& Finance, 34(7): 650-1663.

Hernando, I. and Nieto, M.J. (2007). 'Is the Internet delivery channel changing banks' performance? The case of Spanish banks', Journal of Banking \& Finance, 31(4): 1083-1099.

Higgins, E.J. and Mason, J.R. (2004). 'What is the value of recourse to asset-backed securities? A clinical study of credit card banks’, Journal of Banking \& Finance, 28(4): 875-899.

Ho, G. and Pennington-Cross, A. (2006a). 'The impact of local predatory lending laws on the flow of subprime credit', Journal of Urban Economics, 60(2): 210-228.

Ho, G. and Pennington-Cross, A. (2006b). 'Loan servicer heterogeneity and the termination of subprime mortgages’, Federal Reserve Bank of St. Louis Working Paper \#2006-24.

Ho, G. and Pennington-Cross, A. (2010). 'The termination of subprime hybrid fixed-rate mortgages', Real Estate Economics, 38(3): 399-426.

Jones, D. (2000). 'Emerging problems with the Basel Capital Accord: Regulatory capital arbitrage and related issues', Journal of Banking \& Finance, 24(1): 35-58.

Kane, E.J. (1981). 'Accelerating inflation, technological innovation, and the decreasing effectiveness of banking regulation', Journal of Finance, 36(2): 355-367

Kane, E.J. (2012). 'The inevitability of shadowy banking', SSRN Working Paper. Available at: http://papers.ssrn.com/sol3/papers.cfm?abstract_id=2026229.

Keitel, P.L. (2008). 'The laws, regulations, guidelines, and industry practices that protect consumers that use gift cards', SSRN Working Paper; available at:

http://papers.ssrn.com/sol3/papers.cfm?abstract_id=1266789

Klee, E. (2006). 'Families' use of payment instruments during a decade of change in the U.S. payment system’, Federal Reserve Board, Finance and Economics Discussion Series, \#2006-01.

Krugman, P.R. (2007). 'Innovating our way to financial crisis', New York Times, December 3, 2007; available at http://www.nytimes.com/2007/12/03/opinion/03krugman.html?_r=0. 
Kupiec, P.H. (2000). 'Stress tests and risk capital', Journal of Risk, 2(4): 27-39.

Lax, H, Manti, M., Raca, P. and Zorn, P. (2004). 'Subprime lending: An investigation of economic efficiency, Housing Policy Debate, 15(3): 533-571.

Leitner Y. and Goldstein, I. (2013). 'Stress tests and information disclosure’, Federal Reserve Bank of Philadelphia Working Paper Number 13-26.

Leland, H.E. and Pyle, D.H. (1977). 'Informational asymmetries, financial structure, and financial intermediation’, Journal of Finance, 32(2): 371-387.

Lerner, J. (2002). 'Where does State Street lead? A first look at finance patents, 1971-2000', Journal of Finance, 57(2): 901-930.

Lerner, J (2006). 'The new new financial thing: The origins of financial innovations', Journal of Financial Economics, 79(2): 223-255.

Lerner, J. and P. Tufano. (2011). 'The consequences of financial innovation: A counterfactual research agenda’, Annual Review of Financial Economics, 3(1): 41-85.

Levine, R. (1997). 'Financial development and economic growth: Views and agenda', Journal of Economic Literature, 35(2): 688-726.

Lockwood L.J., Rutherford, R.C. and Herrera, M.J. (1996). 'Wealth effects of asset securitization', Journal of Banking \& Finance, 20(1): 151-164.

Majnoni, G., Martinez-Peria, M.S., Blaschke, W. and Jones, M.T. (2001). 'Stress testing of financial systems: an overview of issues, methodologies, and FSAP experiences', IMF Working Paper \#01/88.

Mantel, B. (2000). 'Why do consumers pay bills electronically? An empirical analysis', Economic Perspectives, Federal Reserve Bank of Chicago, Fourth Quarter: 32-47.

Mantel, B. and McHugh, T. (2001). 'Competition and innovation in the consumer e-payments market? Considering demand, supply, and public policy issues', Federal Reserve Bank of Chicago, Emerging Payments Occasional Working Paper \#EPS-2001-4.

Mayer, C. and Pence, K. (2008). 'Subprime mortgages: What, where, and to whom?' Federal Reserve Board Working Paper \#2008-29.

Mayer, C., Pence, K., and Sherlund, S. (2009). 'The rise in mortgage defaults, Journal of Economic Perspectives, 23(1): 27-50. 
McGrath, J.C. (2005). 'The cost effectiveness of stored value cards for unbanked consumers', Federal Reserve Bank of Philadelphia Payment Card Discussion Paper \#05-06.

Merton, R.C. (1992). 'Financial innovation and economic performance', Journal of Applied Corporate Finance, 4(4): 12-22.

Merton, R.C. (1995). 'Financial innovation and the management and regulation of financial institutions', Journal of Banking \& Finance, 19(3-4): 461-81.

Miller, M.H. (1986). 'Financial innovation: The last twenty years and the next', Journal of Financial and Quantitative Analysis, 21(4): 459-71.

Miller, M.H. (1992). 'Financial innovation: achievements and prospects', Journal of Applied Corporate Finance, 4(4): 4-12.

Molyneux, P. and Shamroukh, N. (1999). Financial Innovation. New York: John Wiley \& Sons.

Myers, S.C. and Majluf, N.S. (1984). 'Corporate financing and investment decisions when firms have information that investors do not have', Journal of Financial Economics, 13(2): 187-221.

Nichols, J., Pennington-Cross, A., and Yezer, A. (2005). 'Borrower self-selection, underwriting costs, and subprime mortgage credit supply', Journal of Real Estate Finance and Economics, 30(2): 197-219.

Pennington-Cross, A. (2003). 'Credit history and the performance of prime and subprime mortgages’, Journal of Real Estate Finance and Economics, 27(3): 279-301.

Pennington-Cross, A. (2006). 'The value of foreclosed property', Journal of Real Estate Research, 28(2): 193-214.

Pennington-Cross, A. and Chomsisengphet, S. (2007). 'Subprime refinancing: Equity extraction and mortgage termination’, Real Estate Economics, 35(2): 233-263.

Plantin, G. (2004). ‘Tranching’, Unpublished Manuscript.

Pritsker, M. (2012). 'Enhanced stress testing and financial stability', Available at: http://papers.ssrn.com/sol3/papers.cfm?abstract_id=2082994.

Quercia, R.G., Stegman, M.A. and Davis, W.R. (2004). 'Assessing the impact of North Carolina’s predatory lending law’, Housing Policy Debate, 15(3): 573-601.

Rose, M.J. (2013). 'Geographic variation in subprime loan features, foreclosures, and prepayments’, Review of Economics and Statistics, 95(2): 563-590. 
Sienkiewicz, S. (2007). 'Prepaid cards: vulnerable to money laundering?’ Federal Reserve Bank of Philadelphia Payment Card Discussion Paper \#07-02.

Smith, S.J. (2013). 'Crisis and intervention in the housing economy: A tale of three markets', in Financial Innovation: Too Much or Too Little? M. Haliassos (ed.), Cambridge, MA: MIT Press, 71-102.

Snowden, K.A. (2010a). 'The anatomy of a residential mortgage crisis: A look back to the 1930s', in The Panic of 2008: Causes, Consequences, and Implications for Reform. L.E. Mitchell and A.E. Wilmarth, Jr. (eds.), Northampton, MA: Edward Elgar Publishing, 51-74.

Snowden, K.A. (2010b). 'Covered farm mortgage bonds in the late nineteenth century U.S.', Journal of Economic History, 70(4): 783-812.

Stavins, J. (2001). 'Effect of consumer characteristics on the use of payment instruments', New England Economic Review, Federal Reserve Bank of Boston, 2001(3): 19-31.

Stavins, J. and Bauer, P.W. (1999). 'The effect of pricing on demand and revenue in Federal Reserve ACH payment processing', Journal of Financial Services Research, 16(1): 27-45.

Sullivan, R.J. (2000). 'How has the adoption of Internet banking affected performance and risk in banks?’ Financial Industry Perspectives, Federal Reserve Bank of Kansas City, December: 1-16.

Thakor, A. (2012). 'Incentives to innovate and financial crises', Journal of Financial Economics, 103(1): 130-148.

Thomas, H. (1999). 'A preliminary look at the gains from asset securitization', Journal of International Financial Markets, Institutions, and Money, 9(3): 321-333.

Thomas, H. (2001). 'The effect of asset securitization on seller claimants', Journal of Financial Intermediation, 10(3/4): 306-330.

Tufano, P. (2003). 'Financial innovation', in Handbook of the Economics of Finance: Volume 1A Corporate Finance. G.M. Constantinides, M. Harris, and R. Stulz (eds.), Amsterdam: North Holland, 307-335.

Van Horne, J.C. (1980). 'Of financial innovations and excesses', Journal of Finance, 40(3): 62136.

Volcker, P.A. (2009). 'Paul Volcker: Think more boldly’, Wall Street Journal, December 14, 2009; available at:

http://online.wsj.com/article/SB10001424052748704825504574586330960597134.html. 
Wilshusen, S.M., Hunt, R.M., van Opstal, J. and Schneider, R. (2012). 'Consumers' use of prepaid cards: A transaction-based analysis', Federal Reserve Bank of Philadelphia Payment Card Discussion Paper \#12-02.

Zinman, J. (2009). 'Debit or credit?’ Journal of Banking \& Finance, 33(2): 358-366. 